\title{
FORMATION AND MANAGEMENT OF REGIONAL AGRI-FOOD CLUSTERS IN DEVELOPING COUNTRIES: CASE OF “AGROTRANSILVANIA” (ROMANIA)
}

\author{
MANUKYAN Izabella ${ }^{1}$ \\ ${ }^{1}$ Russian-Armenian University, Department of Management and Business, Yerevan, Armenia, m.ibella.k@gmail.com
}

\begin{abstract}
Business clusters are considered to be more applicable in countries classified as developed. However, in modern times developing countries take risks of establishing business clusters and get the expected economic and social rewards. The work observes peculiarities of regional agri-food cluster formation and management in developing countries in the frames of the Romanian "AgroTransilvania" cluster. Based on the empirical analysis and the "CIPM" ("Cluster Initiative Performance Model") technique, author conducts an expert assessment and finds out how the cluster's members combine cooperation and competition in order to achieve outstanding results. The research paper encompasses practice-oriented models, including a diamond model for the Romanian agri-food market, a target board of the observed cluster, as well as a map of its members.
\end{abstract}

KEY WORDS: business clusters; agri-food clusters; small- and medium-sized enterprises; SMEs; triple helix

\section{INTRODUCTION}

Today cluster approach to development of enterprises is a highly demanded means that enables countries to strengthen the potential of their regions. Clusters represent structures comprised of core and support businesses that agree on mutual cooperation and competition (Porter, 1996). This phenomenon fosters regional development as well as the rise in overall competitiveness of the countries where clusters are operating. In modern times the concept of business clustering requires active interaction among enterprises, state and educational sectors. Although the best international practice shows that clusters mostly operate successfully in countries that are classified as developed, more and more cases of clusters in developing countries have recently disproved this assumption. Romanian "AgroTransilvania" is a vivid example of an efficiently managed cluster. The peculiarities of the agri-food cluster of the northwestern Transilvania region are thoroughly reviewed in this research paper.

The aim of the research is to conduct a comprehensive analysis of the questions of formation and development of "AgroTransilvania". The country's choice is substantiated by the author's intention to observe a cluster that was created in a developing country, which is more hazardous than in case it operated in a developed country with powerful infrastructure, resource and financial bases. The choice of the particular cluster is justified by its high ranking and the availability of awards from the European Cluster Committee.

\section{RESEARCH METHODOLOGY AND INFORMATIONAL BASE}

During the research, a range of methods were used, including empirical analysis, qualitative analysis as well as quantitative expert evaluation. Apart from that, a "CIPM" ("Cluster Initiative Performance Model") analysis of the research object was conducted (Sölvell et al., 2003). While conducting the research, author was limited in getting insider information from interviews with cluster members. Undoubtedly, this factor puts an impact on the results of the research, but at the same time it reveals the level of transparency of available information as well as gives an opportunity to form the vision of "AgroTransilvania" based on the interviews, research findings and reports that cluster members consider essential to share with public. The informational base was comprised of thematic reports of the World Bank, the International Monetary Fund and other organizations; of analytical documents of state and municipal bodies of Romania; "AgroTransilvania" cluster activity reports and research papers on Romanian regional business development based on clusterization.

\section{GENERAL OVERVIEW OF THE OBSERVED CLUSTER}

Founded in 2013 in the north-western Transilvania region, "AgroTransilvania" declared itself as a cluster initiative coming from the Council of Cluj (the region's central city). At first, it was comprised of 70 members, including producers of food products, trade companies and cooperatives. These key players started to interact with state bodies, universities and research institutions in order to increase the competitiveness of agricultural sector and to foster business restructuring.

Thus, the cluster united representatives of triple helix from business, state and research areas, which is a well-known basis that ensures competitive advantages. Through years, "AgroTransilvania" broadened its influence, strengthened its position and partially entered foreign markets, reaching the number of 84 main partners. The cluster's mission is to support agri-food sector of Transilvania and other regions of Romania by creating conditions for cooperation of representatives from agribusiness, industrial and research sectors.

Since 2019 "AgroTransilvania" has held the "Cluster Management Excellence Label Gold" title of the "European Secretariat for Cluster Analysis" (ESCA, 2021). It is remarkable that in 2014 the cluster was awarded the "Cluster Management Excellence Label Bronze" title, and later received the "Cluster Management Excellence Label Silver" title.

\section{RESULTS OF THE “CIPM” ANALYSIS}

The "Cluster Initiative Performance Model" was developed and presented by Swedish experts in the "Cluster Initiative Greenbook" (Sölvell et al., 2003, pp. 25-30). According to this approach, cluster initiatives should be studied from the position of four categories, each of them including a range of factors. Let us examine "AgroTransilvania" by these categories and factors.

\section{Social, political and economic conditions of the nation}


This category of factors enables to identify how cluster's enterprises interact with the state bodies and the research community. Determinants of competitiveness that represent this category were analyzed with the use of the diamond model (Porter, 1996). Note that the determinants were observed from the position of the relevance to manage an agri-food cluster in Romania. By doing this, author specified the determinants based on particular features of the observed initiative.

\section{1) Factor conditions}

Romania is a country that plays a significant role in the agricultural sector of Europe. Total area of agricultural land of the country and equals to 15 million hectares. Romanian climate conditions foster the development of horticulture (Flanders Investment \& Trade Market Survey, 2017, pp. 4-5). The country's research impact on European science has increased recently. Although the scientific breakthrough of Romania is less rapid than in other countries of Europe, it has become promising and forward-looking (Politico, 2019). Romania is facing a deficit of professional skills on local labor market, which has supposedly been caused by imperfections of the educational system, by the increase in migration flows and by low levels of employee involvement in continuing education (Bellnga et al., 2020). A vivid regional differentiation serves as a barrier for the country's smooth and balanced development (Milatovic \& Szczurek, 2020, pp. 19-20). Overall quality of infrastructure in the year of 2019 was assessed my WEF experts as medium: Romania was ranked $55^{\text {th }}$ out of 141 countries; the deployment of ICT was ranked $32^{\text {nd }}$ (World Economic Forum, 2019, pp. 494-497).

\section{2) Demand conditions}

Romania is highly dependent on imported agri-food products, and the country's trade balance of agricultural products is negative (Panait \& Cucu, 2020, p. 616). Recently there has been witnessed a sharp rise in the demand for diverse products of high quality in Romania, and it serves as an additional difficulty to local food industry enterprises. These businesses are unable to meet the needs of population with their own strengths, which stimulates the import of groceries (Gavrilescu, 2019, p. 30). Nevertheless, this factor creates opportunities for "AgroTransilvania" that is constantly working on the compliance of their products with high quality standards.

\section{3) Related and supporting industries}

There are 52 suppliers of agricultural equipment in Romania, and 5 of them are located in Transilvania (Europages, 2021). All of these enterprises supply tools and inventory essential for agriculture. What comes to businesses from supporting industries, it is notable that Romanian firms are actively involved in the improvement of client loyalty to local food products by organizing advertising campaigns and introducing memorable slogans (Manea \& Epuran, 2016, p. 544).

\section{4) Firm strategy and rivalry}

The issue of agricultural market management is considered problematic in the country. There are several millions of farmers in Romania, each of them owning at least half a hectare mainly for personal use (Barbu, 2019). From time to time, products are sold at local markets, but it does not happen systematically. All local producers of agricultural products follow the same pricing strategy. Prices on agricultural products in Romania are the least expensive of all EU countries. Products are natural and do not contain additives.

Thus, it can be concluded that Romania has a strong potential for agri-food business management. Despite the existence of determinants of unfavourable competitive position, all in all, Romanian agricultural business has promising perspectives.

Let us observe the role that state bodies play in the development of agriculture and "AgroTransilvania". Agricultural development serves as a priority objective of state strategic programmes. The "2014-2020 Rural Development Programme for Romania" is a vivid example of such programmes, for the implementation of which the amount of 9.5 billion euros was allocated. The "2020-2024 Rural Development Programme for Romania", like previous ones, represents a set of measures that should be undertaken in the agricultural sector for rural areas of Romania. The Programme is aimed at supporting and strengthening of regional agri-business by organization of thematic training sessions and consultations for entrepreneurs with a priority for young farmers that manage small-sized businesses. Apart from that, the Programme works on the improvement of the irrigation system as well as on risk management, quality management and the creation of connections between research institutions and farms (European Commission, 2014).

State policy towards the support of SMEs in the agricultural sector is focused on the improvement of Romanian indicators to the level of EU countries. The reduction of polarization in the structure of agricultural enterprises is one of the main governmental objectives. The portion of large and medium-sized enterprises that manage approximately $70 \%$ of agricultural land equals to $7 \%$, whereas the percentage of small-sized enterprises is $93 \%$, and each of them manages around 5 hectares of land. A small-sized business in Romania owns 3.4 hectares on average, but this indicator is lower than the European average, which is equivalent to 14.4 hectares (European Commission, 2014, p.2). The government supports the concept of consolidation of farming lands by integration of small farmers or by land leasing (Feshchenko, 2020). This approach seems attractive to a limited number of farmers, as state subsidies are directly linked to the area of farms.

As a whole, the state allocates resources on identification of clusters and their further strengthening. The Ministry of Economy, Trade and Entrepreneurship of Romania actively works on the development of business clusters. This body is responsible for cluster development in the frames of the state industrial policy. In the year of 2011 there was founded an association entitled "CLUSTERO". At first, the association was comprised of 47 Romanian clusters, and through years this number increased, reaching 76 (CLUSTERO, 2021). One of the main targets of the association is to consolidate all local cluster initiatives and to stimulate the development of clusters on regional, national and international levels, which will eventually lead to the improvement of the country's economic growth. Association members seize the opportunity for experience exchange.

Romania was ranked $55^{\text {th }}$ out of 190 countries in "Doing Business 2020". According to the experts of the World Bank, Romania has improved its indicators of speed and price of opening a business (World Bank, 2020a, pp. 44-49). Apart from that, the country has simplified its tax system. These factors, undoubtedly, better the business environment of Romania and serve as an additional stimulus for the enhancement of entrepreneurship.

Table 1 summarizes the Porter's diamond of Romanian competitive determinants from the position of the relevance to manage an agri-food cluster in the country. 
Table 1. Competitive diamond for the Romanian agri-food market

\begin{tabular}{|c|l|l|}
\hline & \multicolumn{1}{|c|}{ Favourable Competitive Position } & \multicolumn{1}{c|}{ Unfavourable Competitive Position } \\
\hline $\begin{array}{c}\text { Factor } \\
\text { Conditions }\end{array}$ & $\begin{array}{l}\text { + Advantageous natural and climatic conditions. } \\
+ \text { Accelerating pace of the country's research } \\
\text { potential. } \\
\text { + Considerably high level of ICT adoption. }\end{array}$ & $\begin{array}{l}\text { - Deficit of professional skills on local labour market. } \\
\text { - High regional differentiation (the farther regions are } \\
\text { located from the capital, the less developed it is). } \\
\text { - Relatively low quality of road infrastructure. }\end{array}$ \\
\hline $\begin{array}{c}\text { Demand } \\
\text { Conditions }\end{array}$ & $\begin{array}{l}\text { + Rise in the demand of Romanian population } \\
\text { for diverse food products of high quality. }\end{array}$ & - Negative trade balance of agricultural products. \\
\hline $\begin{array}{c}\text { Related and } \\
\text { Supporting } \\
\text { Industries }\end{array}$ & $\begin{array}{l}\text { + Sufficient number of agricultural equipment } \\
\text { suppliers in Romania and in Transilvania region } \\
\text { in particular. }\end{array}$ & $\begin{array}{l}\text { - Insufficient activeness of advertisement of local } \\
\text { agricultural products. }\end{array}$ \\
\hline $\begin{array}{c}\text { Firm Strategy } \\
\text { and Rivalry }\end{array}$ & $\begin{array}{l}\text { + Local producers and exporters of agricultural } \\
\text { products follow the same pricing strategy. }\end{array}$ & $\begin{array}{l}\text { - Indistinct actions of a certain amount of local farmers in } \\
\text { the strategy of production and distribution of agricultural } \\
\text { products. }\end{array}$ \\
\hline
\end{tabular}

Source: Author's research

There are 7 agri-food clusters in Romania that integrated 168 businesses in the period between 2013 and 2017. Thus, the overall revenue from the operation of these clusters stood at $€$ 2.7 billion, while each cluster ensured the job placement of 7280 employees on an annual basis (Muraru-Ionel, 2019, p. 447). It is worth mentioning that within the first year of functioning 22 members of "AgroTransilvania" provided the cluster with $€ 41$ million and contributed to the employment of 793 workers based on the investment expenditures on cluster management and development equaling to $€ 11.4$ million (Fundleanu, 2015, p. 131). These data demonstrate the importance of agri-food clusters for the development of Transilvania as well as for the strengthening of agricultural sector of Romania. Although the country has undertaken a conscious shift from industrial agrarian to service economy, the percentage of agriculture in the GDP in recent years has equaled to $4.5 \%$ on average (World Bank, 2020b).

Most of the cluster's enterprises are classified as small-sized, and 23 regional producers of agricultural food products have access to regional hypermarkets. Each enterprise offers its own products and preserves its autonomy and brand, but at the same time the collective positioning of all members is manifested in the form of an agri-food cluster. To fight for clients, entrepreneurs improve the quality of their products and the value chain.

\section{Objectives of the cluster initiative}

Cluster initiatives may vary depending on their objectives, such as scale of cluster activities, means and amounts of financing, impact on local and foreign organizations, proportions of influence of the authorities and the public, cluster specialization and innovations. Cluster objectives were scrupulously studied in the frames of the "Global Cluster Initiative Survery - GCIS", and, as mentioned in the "Cluster Initiative Greenbook", they can be divided into 6 main segments (AgroTransilvania, 2021, pp. 27-28). It should be noted that the "GCIS" obtained insider information from surveys and interviews with representatives of cluster, whereas the author was limited in getting insider information.

Based on the analysis, a target board with 6 categories of objectives of "AgroTransilvania" was formed. The higher the activity and engagement in the implementation of the objective, the closer the objective is placed to the centre of Figure 1 (segments are divided into semirings from $0 \%$ to $100 \%$ ). Thus, let us scrupulously observe the nature and specific features of each objective of "AgroTransilvania".

\section{1) Research and networking}

"AgroTransilvania" does not publish its financial statements in open access. Nevertheless, it proclaims information concerning its members and partners. Hence, the following key players are a part of "AgroTransilvania" (AgroTransilvania, 2021):

- 3 state bodies and administrative authorities;

- 3 partners from marketing and communication;

- 7 partners from research and education;

- 10 intermediary organizations;

- 61 representatives of cluster's core and supporting sectors.

The description includes information concerning the physical address, telephone number and in some cases website address of the participants. Mostly, the information is indicated in Romanian language, which leads to additional difficulties for the examination of cluster members. Approximately 14\% of the overall number of cluster members were indicated only by names, telephone numbers or e-mail addresses, and the exact identification of their specializations was not possible. Not less importantly, "AgroTransilvania" shows its openness to spread relevant information concerning the events connected with cluster members, about further planning of the cluster's development and its new challenges. As a proof, there are various thematic congresses, meetings of cluster members (especially core enterprises), symposiums, public interviews in Transilvania. Information concerning the cluster's mission, aims and strategic objectives is open to public.

\section{2) Policy action}

"AgroTransilvania" encompasses representatives of the triple helix. The cluster includes the "research-business-government" chain, fostering open cooperation of all three elements. ClujNapoca, Timis, Bihor and Brasov are considered as top university cities of Romania (Reveiu \& Dardala, 2013, p. 558). The cities are located in Transilvania region, and due to high involvement in $\mathrm{R} \& \mathrm{D}$, Transilvanian universities make a significant contribution to the country's research output. "AgroTransilvania" stimulates and appreciates research activities of the youth and eventually implements the results of research findings in order to improve the cluster's operation. Apart from the integration of 7 local members from educational and research sectors ( 3 universities, 3 research institutions and 1 college), "AgroTransilvania" provides students with opportunities to complete internship by taking part in projects on the solution of problems of the cluster's production, marketing and distribution (Rural Romania: National Rural Development Network, 2015, pp. 14-17). 


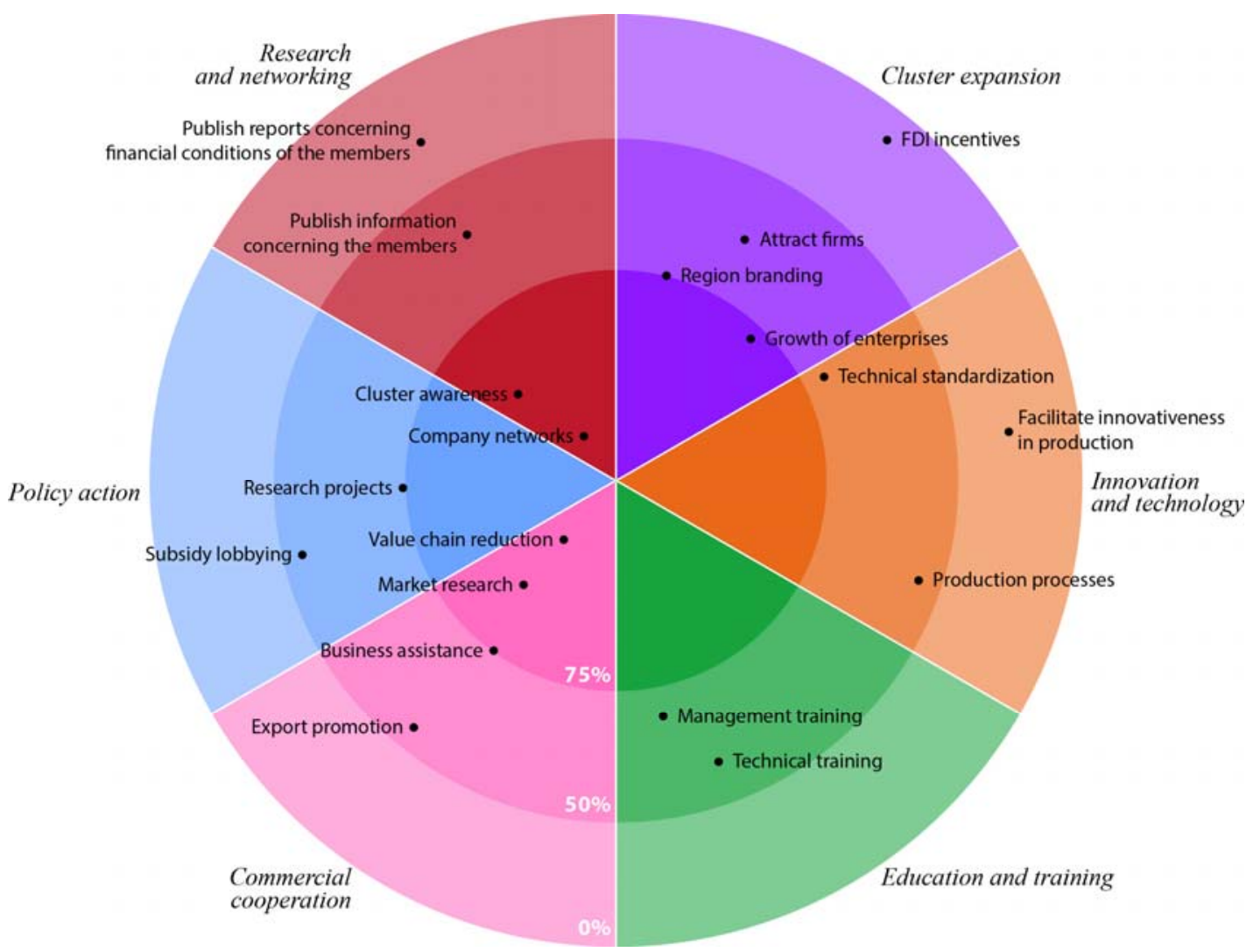

Figure 1. "AgroTransilvania” Target Board

Source: Author's research

Cooperation enables interns to gain rich experience of working in real conditions, and the most useful research findings are later implemented in order to improve the cluster.

The development vector of "AgroTransilvania" does not contradict to the vision of public administration bodies. If necessary, local authorities provide financial support to research institutions and universities to contribute to their research activities. These factors illustrate high involvement of government in the cluster's growth.

\section{3) Commercial cooperation}

Core enterprises of "AgroTransilvania" distribute their goods to local markets under a joint brand named "Transilvania Acasa" (Dragos, 2018). In the frames of this commercial model each producer of fruits, vegetables, jams, meat, cheese, butter and other food products has an opportunity to deliver its natural goods to 2 supermarkets of Cluj-Napoca. Producers, in turn, are required to mention on the packages of goods that they were produced in "AgroTransilvania" cluster. Simultaneously, producers are allowed to mention their brand names on the packages. These actions were established by the cluster's management and serve as an example of value chain reduction that enabled the consolidation of producers and their access to new markets. Thus, members of "AgroTransilvania" (including micro-, small- and medium-sized enterprises) are able to jointly overcome hardships and share risks instead of facing high transactional costs and other losses individually.

"Transilvania Acasa" entered the Romanian market in 2013. Gaining high reputation, it stimulated high interest of other European countries to the products of "AgroTransilvania". Due to the cluster initiative's successful implementation at local markets, the group of enterprises became recognized and reached market expansion.

\section{4) Education and training}

The question of education and advanced training is of high significance to the members of "AgroTransilvania". The cluster organizes training sessions to foster the professional skills of those employed in the cluster, and course duration varies from 2 to 4 days or 6 to 9 hours. Based on the relevance, course programmes differ from Innovation Management, Sales Management, Ogranizational Culture to the Bases of Industrial Hygiene and other topics (AgroTransilvania, 2021). These training sessions encompass staff at various levels and are held by educational and consulting centres of Cluj-Napoca or by lecturers from universities of Transilvania region.

\section{5) Innovation and technology}

"AgroTransilvania" produces its products in accordance with the European quality standards and actively works on the improvement of its production system. This aspect provides the cluster with chances to achieve high levels of development. Nowadays, the quality of a product is hugely dependent on the standards of its production, packaging and storage. Apart from that, the entrance to foreign markets is impossible in case the norms and standards are not followed properly. Enterprises of the cluster use contemporary innovative equipment.

\section{6) Cluster expansion}

The expansion of clusters assumes the attraction of foreign direct investments. According to the official data, Romania encourages FDI three times less than the EU average. The most part of the Romanian FDI is allocated to the industrial sector, and the highest concentration of $60 \%$ is witnessed in BucharestIlfov, whereas in other regions the portions of FDI do not exceed 9\% (Milatovic \& Szczurek, 2020, p. 9). In this respect, the overall intensity of FDI inflows to Romania and Transilvania is not high. 
"AgroTransilvania" aims to improve its image and brand recognition. Currently, 76 clusters operate in Romania, including 7 agri-food clusters. This factor hardens the work of the promotion of "AgroTransilvania", and the cluster needs to strive to raise awareness about "Transilvania Acasa" at local and foreign markets. The cluster's internationalization is carried out in the frames of fairs (in European countries, China, South Korea), matchmaking events (in Europe, Canada, Iran) and conferences (in Canada, Japan, Ukraine, Iraq) (Arion, 2019). Cluster expansion is highly dependent on the brand image and it opens new opportunities to gain profit and to integrate new partners from supporting and core industries.

Hence, the target board summarizes that "AgroTransilvania" accentuates on its objectives related to commercial cooperation, cluster expansion and education and training.
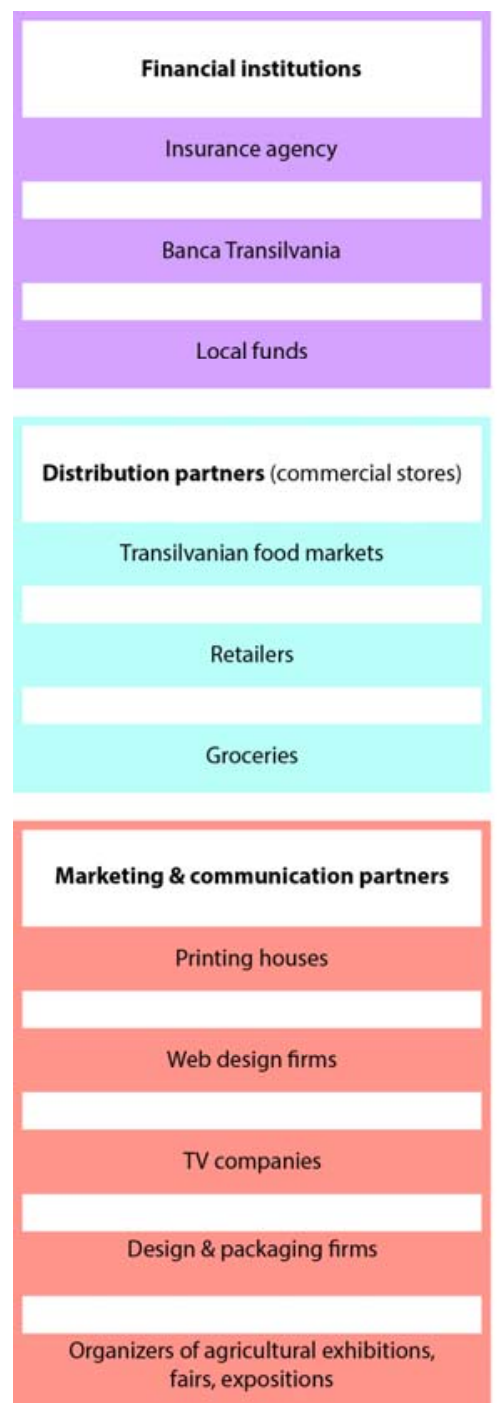

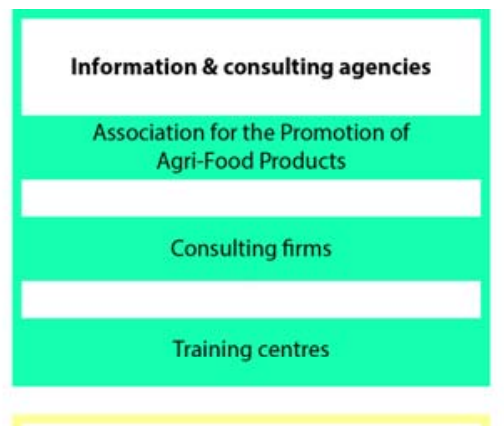

Food distribution points

Fast food restaurants

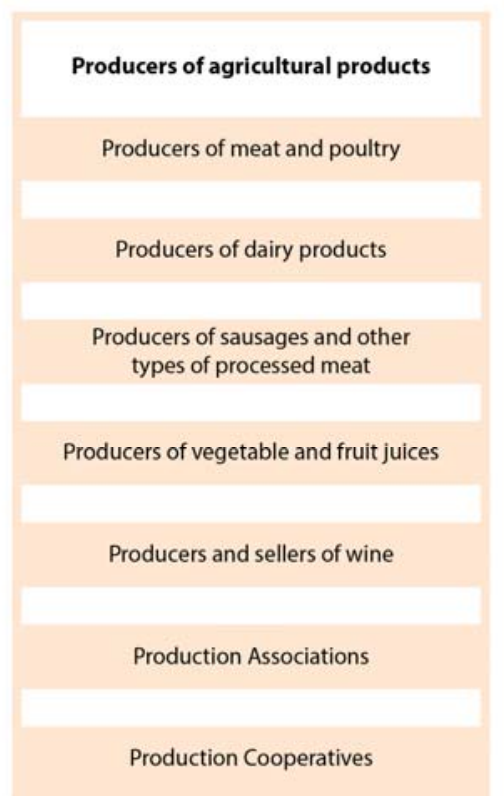

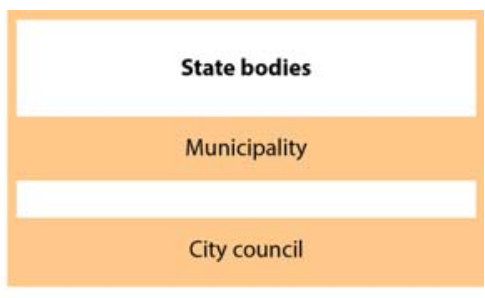

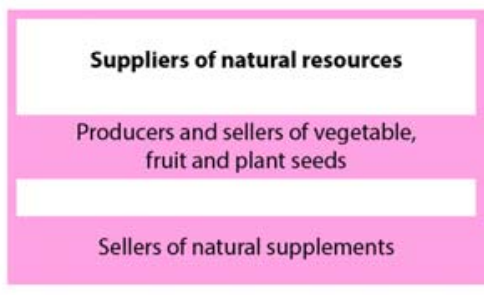

Suppliers of production materials

Producers and sellers of machine tools

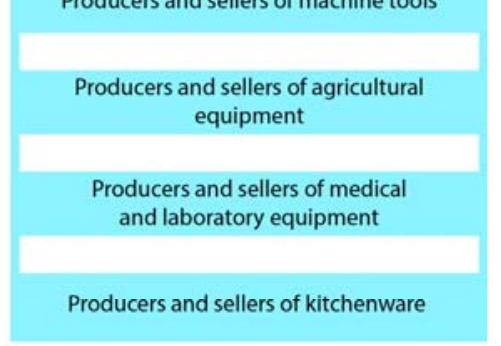

Science and education

Local universities

Local R\&D centres

Figure 2. Map of the members of "AgroTransilvania" cluster

Source: Author's research

\section{The cluster's initiation process}

\section{1) Initiation and planning}

Originally, in the year of 2013, the initiative to establish "AgroTransilvania" came from the Council of Cluj. Nevertheless, in modern times the engagement in planning of the cluster's development is mostly under the supervision of the private rather than the public sector. It should be noted that there exists mutual partnership between business and government in the process of cluster management.

\section{2) Governance and financing}

"AgroTransilvania" attracts finances through individual financial sources of its members as well as with the help of monthly membership fees. Apart from that, the cluster has access to European funds (Török, 2015, p. 423).

\section{3) Scope of membership}

The observation of the cluster's members allowed to come to conclusion that "AgroTransilvania" encompassess local enterprises and branches of foreign enterprises. The cluster is mostly comprised of SMEs, excluding a few large members. The headquarter of "AgroTransilvania" is located in Cluj-Napoca, but the cluster has 5 offices in neighbouring cities (Arion, 2019). Figure 2 represents the map of "AgroTransilvania" members.

The cluster integrates triple helix participants ("researchbusiness-government" chain), financial institutions, marketing and communication partners, as well as sales partners, materials suppliers and suppliers of natural resources that strengthen the cluster's core. 


\section{4) Resources and facilitator}

Felix Arion (economist, Doctor of Business Administration) serves as the general manager of "AgroTransilvania". Professor Arion has worked in more than 20 projects related to the specialization of the cluster. Due to the membership in the cluster, enterprises earn a facilitated access to its resources. For instance, "Sctiehnofavorit SRL" is a supporting member that concentrates on packaging of goods and development of package design. Each enterprise of "AgroTransilvania" is able to cooperate with "Sctiehnofavorit SRL" at minimum cost.

\section{5) Framework and consensus}

"AgroTransilvania" relates to such initiatives where frameworks are scrupulously defined and modified later, as necessary. In case modifications take place, the cluster notifies its members and the public. These factors foster the cluster's openness and transparency of its actions. The vision of "AgroTransilvania" is to support the cooperation of agri-food enterprises and to stimulate the competitive restructurisation of the industry, as well as to guarantee the participation of the cluster in local and international commercial projects. The aim of "AgroTransilvania" is to become an integrating element for the sustainable development of agri-food sector in Transilvania by supporting the industry's sustainability and competitiveness (Martinidis et al., 2019, p. 28).

\section{6) Momentum}

Through years, "AgroTransilvania" increased the number of its firms. The overall contribution of the cluster into the Romanian agri-food sector has also been increased. As the state policy towards agri-food enterprises has changed, it serves as an additional catalyst for the improvement of the cluster's dynamics. For instance, state policy of stimulation of young Romanian farmers' involvement was implemented as a reply to the imperfection of the condition of farmers' age differentiation. As the statistics shows, in the year of 2016 about $44.3 \%$ of farmers in Romania were 65 years, whereas approximately $7.6 \%$ were younger than 40 years (EAFRD, 2020, p.15). "AgroTransilvania" actively works on the integration of young farmers.

\section{Performance}

\section{1) Innovation and international competitiveness}

"AgroTransilvania" initiative has fostered the competitiveness of the cluster's core and supporting enterprises. Working together, the enterprises achieve high results and improve connections in the "research-business-government" chain.

\section{2) Cluster growth}

The growth of "AgroTransilvania" on local market took place as a consequence of the integration of new participants and the establishment of connections with international partners by working successfully on the improvement of the cluster's reputation. The idea of membership in a prestigious cluster serves as an additional stimulus for entrepreneurs to improve their work and to get opportunities to become members of "AgroTransilvania". This eventually betters the work performance of Transilvanian agri-food enterprises.

\section{3) Goal fulfilment}

Based on the existing materials of press releases, research journals, news and TV platforms, it should be noted that "AgroTransilvania" reaches its aims and, if necessary, changes its strategy by updating strategic goals and objectives.

\section{CONCLUSIONS}

Based on the competitiveness diamond model and the "CIPM" analysis, it was revealed that in a developing country with a range of determinants reflecting its unfavourable competitive position it is possible to form regional clusters and successfully manage them. The observation of "AgroTransilvania" showed that the standardization policies in production, distribution and branding led to the popularization of Transilvania and enabled the integration of new partners. Due to the formation of image and good reputation, the cluster represents a stimulus for selfimprovement of those enterprises that have an intention to become a part of it. As a whole, Romanian public and private institutions create conditions that are favourable for clustering.

The cluster did not become a financial burden for the government, and it mostly develops due to the membership fees of its enterprises and through the access to European funds. Research centres and local universities put a significant impact on the cluster's research potential. Hence, it should be concluded that "AgroTransilvania" is a regional cluster, which works on the improvement of positive synergy effect and integrates key players from the "research-business-government" chain, catalyzing their cooperation in order to achieve outstanding results.

\section{REFERENCES}

1. AgroTransilvania. (2021). Members. Retrieved March 17 from https://agrocluster.ro/en/membri/

2. Arion, F. (2019). In the way of internationalisation FoodNet Project. FoodNet final conference, November $27^{\text {th }}$, Liège. Retrieved from http://foodnetproject.eu/reports/Workshop\%202\%20-\%202\%20\%20Felix\%20Arion\%20\%20-\%20ATC.pdf

3. Barbu, P. (2019). A farm cry: Romania's agricultural potential wasted on 19th-century methods. Retrieved from https://business-review.eu/business/agriculture/a-farm-cryromanias-agricultural-potential-wasted-on-19th-centurymethods-204002

4. Bellnga, V. et al. (2020). Addressing Romania's skills deficit to keep pace with an evolving labor market. Retrieved from https://www.brookings.edu/blog/futuredevelopment/2020/07/23/addressing-romanias-skillsdeficit-to-keep-pace-with-an-evolving-labor-market/

5. CLUSTERO. (2021). Clusters in Romania. Retrieved March 18 from https://clustero.eu/about-us/

6. Dragos, I. (2013). Good Practice: AgroTransilvania Cluster Business Model. Interreg Europe. Retrieved March 17, 2021, from https://www.interregeurope.eu/policylearning/goodpractices/item/1256/agrotransilvania-cluster-businessmodel/

7. Ecotec Research \& Consulting. (2004). A Practical Guide to Cluster Development. A Report to the Department of Trade and Industry and the English RDAs, United Kingdom. Retrieved from https://bluetongue1.files.wordpress.com/2008/04/2004-apractical-guide-to-cluster-development-uk-dti.pdf

8. EAFRD. (June, 2020). Financial needs in the agriculture and agri-food sectors in Romania, Retrieved from https://www.fi- 
compass.eu/publication/publications/financial-needsagriculture-and-agri-food-sectors-romania

9. ESCA. (2021). ECEI Gold Label cluster list. Retrieved from https://www.cluster-analysis.org/gold-labelnew/?complete $=1$

10. Europages. (2021). Agricultural machinery and equipment - Romania. Retrieved from https://www.europages.co.uk/companies/Romania/agricult ural $\% 20$ machinery $\% 20$ and $\% 20$ equipment.html

11. European Commission. (2014). Factsheet on 2014-2020 Rural Development Programme for Romania. Retrieved from https://ec.europa.eu/info/sites/info/files/foodfarming-fisheries/key_policies/documents/rdp-factsheetromania_en.pdf

12. Feshchenko, A. (April 7, 2020). Development of LargeScale Farming in Romania: the Role of Policies and Reforms. Retrieved from https://www.largescaleagriculture.com/home/newsdetails/development-of-large-scale-farming-in-romaniathe-role-of-policies-and-reforms/

13. Flanders Investment \& Trade Market Survey. (2017). Agriculture in Romania. Retrieved from https:/www.flandersinvestmentandtrade.com/export/sites/t rade/files/market_studies/2017_Agriculture_Romania.pdf

14. Fundleanu, D. (2015). Quality Audit of the Cluster Management, Instrument of Accreditation at European Level. Annals of the „Constantin Brâncuşi” University of Târgu Jiu, Economy Series, Issue 4, 126-133. Retrieved from http:/www.utgjiu.ro/revista/ec/pdf/201504/18_Fundeanu\%20Daniela.pdf

15. Gavrilescu, C. (2019). An analysis of the trade balance for the main agri-food products. Agrarian Economy and Rural Development - Realities and Perspectives for Romania. International Symposium, $10^{\text {th }}$ Edition, The Research Institute for Agricultural Economy and Rural Development, Bucharest (ICEADR), 26-34. Retrieved from https://www.econstor.eu/bitstream/10419/221837/1/ICEA DR-2019-p026.pdf

16. Manea, L., Epuran, Gh. (2016). The Impact of Advertisements for Romanian Food Products on Consumers. The European Proceeding of Social \& Behavioural Sciences, World LUMEN Congress, 530-544. Retrieved from

https://www.europeanproceedings.com/files/data/article/45 /1222/article_45_1222_pdf_100.pdf

17. Martinidis, G. et al. (2019). Report on the role of clusters and multi-actor networks in the creation of shared value in rural areas. Rubizmo, 25-28. Retrieved from https://rubizmo.eu/attachment/render/434c971f-0533-4f1ea293-9121a719e914

18. Milatovic, J. \& Szczurek, M. (2020). Romania Diagnostic. EBRD Publications. Rertieved from https:/www.ebrd.com/documents/strategy-and-policycoordination/romania-diagnostic.pdf?blobnocache=true
19. Muraru-Ionel, C. et al. (2019) Innovative and CrossSectoral Clusters as Facilitators of Value Added Chains in Agriculture: Smart Agro Clusters in Romania.

Proceedings of the 9th International Scientific Conference Rural Development: Research and Innovation for Bioeconomy, 445-450. http://doi.org/10.15544/RD.2019.067

20. Panait, I. \& Cucu, M. (2020) Romanian Foreign AgriFood Trade in the Context of Global Challenges. Proceedings of the $3^{\text {rd }}$ International Conference on Economics and Social Sciences, 615-623. Retrieved from https://www.researchgate.net/publication/347970495_Rom anian_Foreign_Agri-

Food_Trade_in_the_Context_of_Global_Challenges

21. Politico. (2019). Catching up on research and innovation in Romania. Retrieved from https:/www.politico.eu/sponsored-content/catching-upon-research-and-innovation-in-romania/

22. Porter, M. (1996). Competitive advantage, agglomeration economies, and regional policy. International Regional Science Review, Vol. 19, Issue 1, 85-94

23. Reveiu, A., Dardala, M. (2013). The Role of Universities in Innovative Regional Clusters. Empirical Evidence from Romania. Procedia - Social and Behavioral Sciences 93, 555-559. https://doi.org/10.1016/j.sbspro.2013.09.238

24. Rural Romania: National Rural Development Network (2015), Year II, Issue 26, 14-17. Retrieved from http://www.rndr.ro/en/publications/ruralromania/item/download/128_c1844baab8954b540bbe21e5 1c20b2a6.html

25. Sölvell, Ö., Lindqvist, G., Ketels, Ch. (2003). The Cluster Initiative Greenbook. Stockholm, Sweden: Bromma tryck AB. Retrieved from https:/www.hhs.se/contentassets/f51b706e1d644e9fa6c4d 232abd09e63/greenbooksep03.pdf

26. Török, G. (2015). Cluster Management Practices in Romania and Their Impact on the Development of Local Clusters. Proceedings of the 5th International Conference on Management: Management, leadership and strategy for SMEs' competitiveness, 419-424. Retrieved from http://real.mtak.hu/24773/1/ICoM_2015-paper078.pdf

27. World Economic Forum. (2019). The Global Competitiveness Report, 2019 // Edited by Klaus Schwab. Retrieved from http://www3.weforum.org/docs/WEF_TheGlobalCompetit ivenessReport2019.pdf

28. AgroTransilvania. (2021). Trainings. Retrieved March 19 from http://agrocluster.ro/en/cursuri/

29. World Bank. (2020a). Doing Business - 2020. Economy Profile Romania. Retrieved from https://www.doingbusiness.org/content/dam/doingBusines s/country/r/romania/ROM.pdf

30. World Bank. (2020b). World Development Indicators: Structure of output. Retrieved from http://wdi.worldbank.org/table/4.2 